\title{
Pembelajaran Inovatif di Sekolah Dasar Berdasarkan Paradigma Teori Belajar Humanistik
}

Miki Yuliandri

Mahasiswa Program Doktor Ilmu Pendidikan Universitas Negeri Padang

micky.yuliandri@gmail.com

\begin{abstract}
ABSTRAK
Penelitian ini bertujuan untuk menggambarkan paradigma teori belajar humanistik dalam mengimplementasikan pembelajaran inovatif di sekolah dasar. Metode yang digunakan dalam penelitian ini yaitu metode library research yang data-datanya berasal dari berbagai sumber, baik dari perpustakaan maupun berbagai website yang ada di internet meliputi buku, ensiklopedi, kamus, jurnal, dokumen, majalah, dan lain-lain. Teknik pengumpulan data yang digunakan dalam penelitian ini adalah dokumentasi. Selanjutnya, teknik analisis data yang digunakan dalam penelitian ini yaitu analisis isi. Hasil penelitian ini berusaha menggambarkan bahwa pembelajaran inovatif merupakan pembelajaran yang dirancang oleh guru yang sifatnya baru, untuk menfasilitasi peserta didik dalam membangun pengetahuannya pada proses perubahan perilaku. Di samping itu, teori belajar humanistik merupakan sebuah teori yang membantu peserta didik untuk senang belajar pada suatu objek atau materi pelajaran dalam mengembangkan potensi diri peserta didik ke arah yang lebih baik. Dengan demikian teori belajar humanistik dapat digunakan untuk mengimplementasikan pembelajaran inovatif di sekolah dasar. Teori belajar humanistik menekankan pada pendidikan membimbing, mengembangkan dan mengarahkan potensi dasar peserta didik baik dari segi kognitif, afektif, dan psikomotor.
\end{abstract}

Kata kunci: teori belajar, humanistik, pembelajaran inovatif

\begin{abstract}
This research aims to describe the paradigm of humanistic learning theory in implementing innovative learning in elementary school. The method used in this research is library research which data comes from various sources, both from libraries and various websites that exist on the internet. The sources are books, encyclopedias, dictionaries, journals, documents, magazines, and others. Techniques in collecting data that used in this study is documentation. Furthermore, the data analysis technique used in this research is content analysis. The results of this study attempt to illustrate that innovative learning is a learning designed by teachers in new way. The new design made to facilitate learners in building knowledge in the process of behavior change. The theory of humanistic learning is a theory that helps learners to enjoy learning on subject matter in developing the potential of students themselves to a better direction. Thus, humanistic learning theory can be used to implement innovative learning in primary schools. Humanistic learning theory emphasizes guidance education, develops and directs students basic potential in terms of cognitive, affective, and psychomotor.
\end{abstract}

Keywords: learning theory, humanistic, innovative learning

This work is licensed under the Creative Commons Attribution-ShareAlike 4.0 International License. (C2017 by the author(s).

Received: October 172017

Revised: November 242017

Accepted: December 12017

\section{PENDAHULUAN}

Proses pembelajaran merupakan suatu kegiatan yang dilaksanakan oleh guru 
dalam menyampaikan materi kepada peserta didik untuk mencapai tujuan pendidikan yang telah ditetapkan. Tujuan pendidikan pada dasarnya mengajak peserta didik menuju pada perubahan tingkah laku yang dilihat dari segi intelektual, emosional, mental, maupun sosial (Sanusi, 2013). Di lihat dari kenyataannya pada hasil wawancara dengan beberapa peserta didik kelas V SDN Mangunharjo 02 diperoleh hasil bahwa penyebab rendahnya aktivitas belajar dikarenakan peserta didik merasa jenuh dengan cara mengajar guru. Peserta didik merasa bosan karena hanya duduk diam mendengarkan guru menjelaskan materi pembelajaran. Hal itu mengakibatkan peserta didik kesulitan dalam menyerap materi pembelajaran, terutama untuk peserta didik dengan gaya belajar visual dan audio visual (Susanti, Wahjoedi, dan Utaya, 2016).

Selanjutnya, dari hasil wawancara dengan guru kelas V SDN Mangunharjo 02 diperoleh hasil bahwa dalam proses pembelajaran, materi yang disampaikan guru menggunakan metode ceramah secara klasikal. Oleh karena itu, mengakibatkan materi pembelajaran mudah hilang dari ingatan peserta didik sehingga pembelajaran masih berpusat pada guru (teacher centered) (Susanti, Wahjoedi, dan Utaya, 2016). Selain itu guru juga jarang menggunakan media pembelajaran, penggunaan media pembelajaran hanya terbatas pada gambar-gambar yang ada pada buku teks. Dengan demikian, mengakibatkan proses pembelajaran menjadi membosankan dan potensi peserta didik tidak dapat dikembangkan secara optimal (Hia, Sumarni, dan Armiati, 2016).

Menurut Aswita (2015), pendidikan yang berkualitas akan terwujud jika didukung oleh pembelajaran yang berkualitas. Dalam mengembangkan potensi peserta didik seorang guru harus mampu menciptakan pembelajaran yang kreatif dan inovatif. Hal ini karena keberhasilan pendidikan ditentukan oleh bagaimana proses pembelajaran berlangsung. Sekolah sebagai sistem penyelenggara pendidikan harus memberdayakan seluruh komponen yang ada di dalamnya secara terpadu dan saling berkaitan antara satu dengan yang lain sehingga mendorong tercapainya tujuan pendidikan (Hera, 2017). Pembelajaran inovatif adalah pembelajaran yang bertujuan meningkatkan perilaku kreatif, menggerakkan potensi kreativitas peserta didik terhadap hal-hal yang baru (Mustami, 2015). Pembelajaran inovatif mengarah pada pembelajaran yang berpusat pada peserta didik, pembelajaran tersebut dirancang, disusun, dan dikondisikan untuk menumbuhkan motivasi peserta didik dalam belajar.

Pembelajaran inovatif digunakan guru bertujuan untuk mengembangkan pengetahuan peserta didik pada proses perubahan perilaku. Untuk mengubah perilaku peserta didik ke arah yang lebih baik dibutuhkan teori belajar humanistik dalam pembelajaran inovatif di sekolah. Pembelajaran humanistik merupakan salah satu pembelajaran yang dapat mengembangkan sikap saling menghargai dan mengembangkan potensi yang ada pada diri peserta didik. Konsep belajar teori humanistik tidak hanya memberikan pengetahuan kepada peserta didik, tetapi mengajak untuk menghayati, menyelami, dan memahami berbagai bentuk potensi yang ada pada peserta didik (Anam, 2014). Dengan demikian, pembelajaran inovatif dimanfaatkan sebagai kegiatan pembelajaran dalam proses pendidikan.

Dalam proses pembelajaran di kelas, ada lima komponen penting yang 
membentuk satu kesatuan lingkungan pembelajaran, yaitu tujuan, pendidik, peserta didik, materi, dan evaluasi. Dari kelima komponen tersebut, pendidik merupakan penggerak aktif agar pembelajaran berjalan secara efektif dan efisien (Widyaningrum dan Rahmanumeta, 2016). Oleh sebab itu untuk menjalankan kelima komponen di atas guru sebagai tenaga pendidik perlu menggunakan strategi pembelajaran yang inovatif dalam menentukan keberhasilan dan perubahan tingkah laku peserta didik. Strategi pembelajaran inovatif diterapkan dalam penyampaian materi dengan menghubungkan fenomena yang dialami peserta didik dalam kehidupan sehari-hari (Sarwi, Supriyadi, dan Sudarmin, 2013). Dengan demikian, pemilihan strategi pembelajaran didasari pada berbagai pertimbangan sesuai dengan situasi, kondisi, dan lingkungan yang akan dihadapi. Pemilihan strategi pembelajaran bertujuan untuk mengembangkan potensi-potensi yang ada pada peserta didik baik dari segi kognitif, afektif, dan psikomotor. Tujuan penelitian ini untuk menggambarkan paradigma teori belajar humanistik dalam mengimplementasikan pembelajaran inovatif di sekolah.

\section{METODE PENELITIAN}

Metode yang digunakan dalam penelitian ini yaitu metode library research. Di lihat dari pengertiannya metode library research yaitu metode yang data-datanya diperlukan dalam menyelesaikan suatu penelitian yang berasal dari sumber perpustakaan yang meliputi buku, ensiklopedi, kamus, jurnal, dokumen, majalah, dan lain sebagainya (Harahap, 2014) serta berbagai sumber yang ada di internet. Teknik pengumpulan data yang digunakan dalam penelitian ini adalah dokumentasi. Menurut Arikunto dokumentasi yaitu mencari data mengenai hal-hal yang berupa catatan, buku, makalah, artikel, jurnal, dan sebagainya (Purwoko, 2017). Selanjutnya, teknik analisis data yang digunakan dalam penelitian ini yaitu analisis isi. Dalam analisis ini akan dilakukan proses memilih, membandingkan, dan menggabungkan berbagai pengertian sehingga ditemukan yang relevan (Purwoko, 2017).

\section{HASIL PENELITIAN}

\section{Teori Belajar Humanistik}

Istilah Humanistik berasal dari kata latin humanitas (pendidikan manusia) dalam bahasa Yunani disebut Paideia, pendidikan yang didukung oleh manusiamanusia yang hendak menempatkan seni liberal yang dijadikan materi atau sarana utamanya (Abidin, 2002:27). Kata humanistik pada hakikatnya berbentuk kata sifat yang menitikberatkan pada pendekatan di dalam pendidikan (Mulkhan, 2002:95). Pendidikan humanistik memfokuskan pada pendidikan yang menjalin komunikasi dan relasi personal antara pribadi-pribadi dan kelompok di dalam komunitas sekolah (Arbayah, 2013). Dengan demikian hakikat pendidikan sesungguhnya untuk mengembangkan harkat dan martabat manusia (human dignity) atau memperlakukan manusia sebagai humanizing human sehingga menjadi manusia sesungguhnya (Armiati, 2016)

Menurut Alauddin (2015) teori belajar humanistik adalah teori belajar yang membantu peserta didik untuk senang belajar pada suatu objek atau materi pelajaran yang berhubungan dengan aspek-aspek kemanusiaan. Tujuan belajar 
menurut aliran humanistik untuk memanusiakan manusia. Proses belajar dianggap berhasil jika peserta didik memahami lingkungan dan dirinya sendiri (Arbayah, 2013). Oleh sebab itu pendidikan dalam pandangan teori belajar humanistik mampu mengakomodasi semua kepentingan stakeholder dalam dunia pendidikan. Hal ini karena pendidikan humanistik ditafsirkan sebagai pendidikan yang diarahkan untuk semua komponen pendidikan, yang tidak hanya berorientasi pada humanisme siswa tetapi juga pada guru (Riyanton, 2015)

Menurut Yasin (2017) teori humanistik memandang proses belajar ditujukan untuk kepentingan memanusiakan manusia. Oleh sebab itu, teori belajar humanistik sifatnya lebih abstrak dan lebih mendekati bidang kajian filsafat, teori kepribadian, dan psikoterapi, dari pada bidang kajian psikologi belajar. Teori humanistik sangat mementingkan apa yang dipelajari dari pada proses belajar itu sendiri. Teori belajar humanistik lebih banyak berbicara tentang konsep-konsep pendidikan untuk membentuk manusia yang dicita-citakan, serta tentang proses belajar dalam bentuknya yang paling ideal. Menurut Rofikoh (2014) pembelajaran humanistik memberi kebebasan kepada peserta didik untuk mengungkapkan pendapat. Guru sebagai tenaga pendidik tidak berhak mencela atau mengkritik peserta didik, karena peserta didik diperlakukan sebagai subjek dan bukan sebagai objek pembelajaran. Dengan demikian melalui pembelajaran humanistik peserta didik diharapkan aktif dalam belajar dalam mengembangkan potensi dirinya.

\section{Tokoh-Tokoh Teori Belajar Humanistik Arthur Combs}

Arthur Combs merupakan salah satu tokoh aliran humanistik yang menyumbangkan pemikirannya berkaitan tentang dunia pendidikan. Arthur Combs (1912-1999) bersama dengan Donald Snygg (1904-1967) mengemukakan konsep meaning (makna atau arti) dalam proses belajar. Menurut konsep meaning (makna atau arti) belajar terjadi apabila mempunyai arti bagi individu tersebut. Maksudnya guru tidak bisa memaksakan materi yang tidak disukai atau tidak relevan dengan kehidupan peserta didik, Misalnya peserta didik tidak bisa matematika atau sejarah bukan karena mereka bodoh tetapi karena terpaksa dan merasa tidak ada alasan yang penting mempelajari pelajaran tersebut (Wigati dan Muhtarom, 2017). Oleh sebab itu, seharusnya guru lebih memahami perilaku peserta didik dengan mencoba memahami persepsi peserta didik, sehingga apabila guru merubah perilaku peserta didik, guru harus berusaha merubah keyakinan atau pandangan peserta didik tersebut (Haris, 2016).

Menurut Combs untuk mengerti tingkah laku peserta didik, yang perlu dipahami adalah mengerti bagaimana dunia itu dilihat dari sudut pandang peserta didik. Pernyataan tersebut salah satu dari pandangan humanistik mengenai perasaan, persepsi, kepercayaan, dan tujuan tingkah laku inner (dari dalam) yang membuat peserta didik berbeda dengan peserta didik lainnya (Muniroh, 2011). Perasaan, persepsi, dan keyakinan termasuk dalam perilaku-perilaku batiniah yang menyebabkan peserta didik berbeda dengan peserta didik yang lain. Menurut Combs, perilaku yang keliru terjadi karena tidak adanya kesediaan seseorang melakukan apa yang seharusnya dilakukan sebagai akibat dari adanya sesuatu lain 
yang lebih menarik. Maksudnya siswa malas belajar karena ada sesuatu yang lebih menarik di dalam pikirannya (di luar kelas mungkin menyenangkan). Hal ini menyebabkan peserta didik tidak semangat dalam belajar (siswa bosan). Untuk memecahkan masalah tersebut guru harus mengambil tindakan dengan cara mengadakan aktivitas-aktivitas yang menarik yang dapat merangsang semangat siswa dalam proses belajar (Rachmahana, 2008).

Dalam pembelajaran, informasi baru yang didapatkan peserta didik akan dipersonalisasikan ke dalam dirinya. Menurut Combs proses personalisasikan tersebut terbagi atas dua lingkaran, yaitu lingkaran kecil (gambaran dari persepsi diri dan lingkungan) dan lingkaran besar (gambaran persepsi dunia) (Mayasari, 2017). Hal itu menyatakan semakin jauh peristiwa-peristwa tersebut dari "persepsi diri" semakin berkurang pengaruhnya pada peserta didik. Sebaliknya semakin dekat peristiwa-peristiwa tersebut dari "persepsi diri", semakin besar pengaruh terhadap peserta didik (Hilmi, 2012). Maksudnya, dalam proses pembelajaran, guru perlu memahami dunia peserta didik dalam rangka mengubah pandangannya. Pendidik dalam pandangan filsafat pendidikan humanisme perlu memberikan materi pembelajaran yang berhubungan dengan apa yang dibutuhkan peserta didik sehingga memiliki dampak yang bermakna bagi peserta didik (Mayasari, 2017).

\section{Abraham Maslow}

Abraham Maslow dilahirkan di New York pada tahun 1908 dan meninggal tahun 1970. Teori Maslow yang terkenal yaitu teori Hierarchy of Needs atau hirarki kebutuhan. Teori ini dapat diterapkan pada semua ilmu pengetahuan, termasuk ilmu pendidikan. Abraham Maslow dianggap sebagai bapak psikologi humanistik yang menggabungkan aspek-aspek psikologi behavioral dan psikologi psikoanalistik. Menurut Maslow manusia mempunyai kemampuan unik untuk membuat pilihan dan melaksanakan pilihan tersebut (Mendari, 2010). Berdasarkan teori hirarki kebutuhan, Maslow menjelaskan beberapa kebutuhan dapat memotivasi seseorang (peserta didik). Maslow mengungkapkan terdapat dua macam kebutuhan dalam diri seseorang, yaitu kebutuhan dasar dan kebutuhan untuk bertumbuh (berkembang). Teori Hirarki kebutuhan menjelaskan bagaimana seseorang berperilaku untuk memenuhi kebutuhannya dengan cara bertingkat, yaitu dimulai dari kebutuhan pada tingkat yang paling rendah, paling dasar, dan kebutuhan pada tingkat yang lebih tinggi (Choirudin, 2013)

Menurut Ansyar (2015:186) teori hirarki kebutuhan Maslow terbagi atas lima bagian, yaitu (1) kebutuhan fisiologis (physiological needs) seperti, kebutuhan makanan, minuman, tempat tinggal, istirahat, dan udara, (2) kebutuhan rasa aman (safety needs) seperti, keamanan, stabilitas, proteksi, kebebasan dari rasa takut dan cemas, (3) kebutuhan atas kasih sayang (love and belonging needs) seperti kebutuhan disayangi orang tua, saudara, teman, dan masyarakat, (4) kebutuhan berprestasi (esteem needs), seperti kebutuhan untuk menghargai diri sendiri serta diakui oleh orang lain, dan (5) kebutuhan aktualisasi diri (self-actualization needs) seperti kebutuhan yang ingin menjadikan diri sendiri sebagai pribadi yang lebih baik. Menurut Maslow hirarki kebutuhan merupakan suatu pola yang tipikal dan bisa dilaksanakan pada hampir setiap waktu. Pemenuhan kebutuhan yang satu akan 
menimbulkan getaran pada kebutuhan yang lain. Setiap orang (peserta didik) mempunyai kebutuhan yang berbeda-beda (Mendari, 2010)

Kelima bagian dari teori hirarki kebutuhan tersebut saling berkaitan antara satu dengan yang lain berdasarkan tingkat motivasi yang dapat berpengaruh terhadap motivasi peserta didik dalam belajar. Menurut Rachmahana (2008), pada proses belajar apabila seorang peserta didik sulit memahami suatu pelajaran, guru tidak boleh langsung menyalahkan peserta didik karena tidak memperhatikannya dalam menerangkan pelajaran, barangkali ada proses kebutuhan yang tidak terpenuhi oleh peserta didik tersebut. Bisa jadi peserta didik belum makan, semalam tidur tidak nyenyak, atau ada masalah pribadi dan keluarga yang membuat motivasi peserta didik menurun pada proses belajar. Menurut Moeheriono (2006), Maslow mengasumsikan peserta didik berusaha memenuhi kebutuhan pokok sebelum mengarahkan perilakunya untuk memenuhi kebutuhan yang lebih tinggi. Maksudnya, kebutuhan tersebut saling terhubung antara satu dengan yang lain. Oleh sebab itu, seorang guru harus mempunyai naluri yang kuat dalam mendeteksi keadaan atau kondisi peserta didik dalam proses pembelajaran.

\section{Carl R. Rogers}

Carl R. Rogers merupakan anak keempat dari pasangan Walter dan Julia Cushing, Rogers lahir pada tanggal 8 Januari 1902 di Oak Park, Illinios, Chicago, (Ratu, 2014). Carl R. Rogers seorang ahli psikologi humanistik yang gagasangagasannya berpengaruh terhadap pikiran dan praktek pendidikan (Sudiarta, Sukadi, dan Tegeh, 2014). Di dalam konsep belajar, Rogers mengutarakan pendapatnya tentang prinsip-prinsip belajar yang humanistik. Prinsip-prinsip tersebut meliputi hasrat untuk belajar, belajar yang berarti, belajar tanpa ancaman, belajar atas inisiatif sendiri, dan belajar untuk perubahan (Anam, 2014). Belajar dalam pandangan Rogers bertumpu pada prinsip kebebasan dan perbedaan individu (peserta didik) dalam pendidikan. Oleh sebab itu peserta didik akan lebih mengenal dirinya, menerima dirinya, dan merasa bebas dalam memilih dan berbuat menurut individualitas dengan penuh tanggung jawab (Hanafy, 2014).

Menurut Rogers, teori humanistik menekankan emotional process dan bukan pada intelectual process. Maksudnya bukan apa yang dipikirkan atau dilakukan peserta didik, tetapi bagaimana peserta didik mengalami dan merasakan kehidupannya (Atamimi, 2015). Pendidikan bukan sekadar aktivitas yang di dalamnya terjadi transfer ilmu, tetapi pendidikan dapat membuat peserta didik mampu mengembangkan dan mengeksplorasi potensi diri, kecerdasan emosi, dan makna eksistensi dalam masyarakat (Manurung, 2012). Hal ini karena peserta didik tidak hanya belajar di kelas, tetapi juga belajar di lingkungan keluarga dan lingkungan tempat tinggal. Peserta didik tidak hanya belajar dari buku, tetapi juga belajar dari alam sekelilingnya. Oleh sebab itu, guru sebagai tenaga pendidik harus jeli memilih bahan ajar yang sarat dengan nilai-nilai akhlak dan moral. Dalam proses pembelajaran, guru mesti menggunakan metode yang melatih peserta didik menjadi individu yang humanistik dengan mengapresiasi nilai-nilai lokal yang mendidik, positif, dan berbudi luhur (Manurung, 2012).

Teori belajar humanistik yang dikemukakan oleh Rogers menitikberatkan 
pada metode student-centered dengan menggunakan komunikasi antar pribadi yang berpusat pada peserta didik dalam mengembangkan potensi-potensi yang dimilikinya (Wahyudin, 2009). Oleh sebab itu peran guru dalam kegiatan belajar sebagai fasilitator yang dapat membantu peserta didik dalam memahami suatu pelajaran. Menurut Yanasari (2016), peran guru dalam membantu peserta didik yang dikemukakan oleh Roger, sebagai berikut: (1) guru membantu menciptakan iklim kelas yang kondusif agar peserta didik bersikap positif terhadap belajar, (2) guru membantu peserta didik untuk memperjelas tujuan belajar dan memberikan kebebasan kepada peserta didik untuk belajar, (3) guru membantu peserta didik dalam memanfaatkan impian dan cita-citanya sebagai salah satu kekuatan untuk mendorong peserta didik dalam belajar, (4) guru menyediakan berbagai sumber belajar kepada peserta didik, dan (5) guru menerima pertanyaan dan pendapat peserta didik dalam memahami suatu masalah pada proses belajar.

\section{Pembelajaran Inovatif}

Kata "inovatif" berasal dari kata sifat bahasa Inggris innovative. Menurut Suharmanto (2008:10), kata innovative berakar dari kata kerja yang mempunyai arti menemukan sesuatu yang baru. Oleh karena itu, pembelajaran inovatif merupakan pembelajaran yang dirancang oleh guru yang sifatnya baru, bertujuan untuk menfasilitasi peserta didik dalam membangun pengetahuannya pada proses perubahan perilaku ke arah yang lebih baik sesuai dengan potensi dan perbedaan yang dimiliki peserta didik. Pembelajaran inovatif menghindari pembelajaran konvensional yang masih berpusat pada guru pada kegiatan belajar mengajar. Oleh sebab itu, pembelajaran inovatif diciptakan untuk mendukung terciptanya kelas yang berpusat pada peserta didik. Pembelajaran inovatif menekankan pada pembelajaran menarik, menyenangkan, dan dapat memfasilitasi perkembangan kebutuhan peserta didik di sekolah (Munawar, Prasetyo, dan Pusari, 2013).

Menurut Marzuki (2017) pembelajaran inovatif mempetimbangkan karakteristik peserta didik, kondisi lingkungan peserta didik, dan sarana-prasarana yang tersedia, sehingga lebih menantang dan menumbuhkembangkan semangat peserta didik untuk belajar secara mandiri yang mempermudah pencapaian tujuan belajar. Pembelajaran inovatif menghubungkan pengalaman siswa dengan melihat makna pada materi yang dipelajari dengan cara menyatukan subyek akademik dengan konteks kehidupan yang mencakup konteks keadaan pribadi, sosial, dan budaya. Pembelajaran inovatif menekankan pada proses keaktifan belajar peserta didik, yang difokuskan pada penerapan pengetahuan dalam kehidupan peserta didik, sehingga pembelajaran terasa lebih bermakna bagi peserta didik itu sendiri. Karakteristik pembelajaran inovatif mempresentasikan proses belajar melalui aktivitas mengidentifikasi, merancang, menyelesaikan, dan mengevaluasi pemecahan masalah yang dilakukan peserta didik. Dalam hal ini, peserta didik menggunakan pengetahuan dan pengalaman yang dimilikinya baik secara individual maupun kelompok untuk menemukan pengetahuan baru (Sarwi, Supriyadi, dan Sudarmin, 2013)

Pembelajaran inovatif menempatkan peserta didik sebagai individu yang memiliki pengetahuan dasar dan mencoba mengembangkan pengetahuan dasar 
tersebut menjadi sesuatu yang baru. Hal itu tidak terlepas oleh bimbingan dari beberapa guru di sekolah. Peserta didik terlibat aktif dalam proses pembelajaran mulai dari awal pertemuan sampai akhir pembelajaran (Sunardi, 2015). Oleh sebab itu, guru berusaha memfalitasi peserta didik dalam mengembangkan potensi dirinya. Di samping itu guru ikut berperan dalam memberikan beberapa rangsangan kepada peserta didik untuk mengembangkan pengetahuan dasar yang dimilikinya. Pembelajaran inovatif lebih menekankan pada pembelajaran yang bersifat student centered, maksudnya, pembelajaran yang lebih memberikan peluang kepada peserta didik untuk mengkonstruksikan pengetahuan secara mandiri (self directed) dan dimediasi oleh teman sebaya (peer mediated instruction) (Rahmawati, 2016).

\section{Strategi Pembelajaran Inovatif di Sekolah Dasar}

Strategi pembelajaran inovatif merupakan salah satu faktor yang berperan dalam menentukan keberhasilan dan perubahan tingkah laku peserta didik. Pembelajaran dikatakan efektif apabila dapat memfasilitasi peserta didik untuk mencapai tujuan pembelajaran yang telah ditentukan (Widyaningrum dan Rahmanumeta, 2016). Strategi pembelajaran memfokuskan pada kegiatan pembelajaran yang dilakukan guru dan peserta didik untuk menciptakan pembelajaran yang efektif dan efisien. Pemilihan strategi pembelajaran pada dasarnya merupakan salah satu hal penting yang harus dipahami oleh setiap guru. Hal tersebut karena proses pembelajaran merupakan proses komunikasi ilmiah antara peserta didik, guru dan lingkungan belajar. Strategi pembelajaran yang dipilih oleh guru didasari pada berbagai pertimbangan sesuai dengan situasi, kondisi, dan lingkungan yang akan dihadapi (Rahmi, 2013).

Menurut Aini dan Sudira (2015) salah satu keberhasilan peserta didik dalam pendidikan ditunjukkan dengan hasil belajar. Pada kenyataannya hasil belajar peserta didik semakin tinggi sementara strategi pembelajaran tidak diperbaharui. Hal ini menyebabkan peserta didik kurang kreatif dan menyebabkan hasil belajarnya di bawah kompetensi yang telah ditetapkan. Fungsi pendidikan membentuk sikap dan orientasi peserta didik terhadap belajar, menggunakan strategi pembelajaran yang tepat dapat menanamkan pengetahuan dan mengembangkan keterampilan belajar secara efektif. Peningkatan hasil belajar peserta didik dalam pembelajaran dipengaruhi oleh berbagai faktor, salah satunya yaitu faktor pemilihan strategi pembelajaran. Strategi pembelajaran menekankan pada pendekatan pengajaran dalam mengelola kegiatan pembelajaran untuk menyampaikan materi secara sistematis sehingga kemampuan peserta didik dapat dikuasai secara efektif dan efisien (Siregar dan Situmorang, 2014).

Menurut Hidayat (2008) dalam menentukan keberhasilan strategi pembelajaran, karakteristik peserta didik merupakan hal yang perlu diperhatikan oleh guru. Oleh sebab itu Dick dan Carey menerapkan komponen-komponen strategi pembelajaran yang akan diterapkan guru, yaitu: (1) kegiatan pembelajaran pendahuluan, maksudnya pada bagian ini guru diharapkan mampu merangsang motivasi peserta didik atas materi yang diajarkan, (2) penyampaian informasi, maksudnya informasi yang disampaikan guru dapat ditangkap oleh peserta didik, 
(3) partisipasi peserta didik, maksudnya proses pembelajaran akan lebih berhasil apabila peserta didik secara aktif melakukan latihan secara langsung dengan tujuan pembelajaran, (4) tes, maksudnya serangkaian tes yang digunakan guru dalam mengukur kemampuan peserta didik sesuai pada tujuan pembelajaran, dan (5) kegiatan lanjutan, maksudnya berdasarkan hasil tes yang dilakukan, dilanjutkan dengan aktifitas remedial sebagai solusi akhir untuk menyempurnakan pengetahuan yang diperoleh oleh peserta didik (Sunhaji, 2008).

\section{PEMBAHASAN}

Dalam mengimplementasikan teori belajar humanistik pada pembelajaran inovatif di sekolah dasar, guru sebagai tenaga pendidik merupakan salah satu faktor penentu dalam mencapai kompetensi belajar. Keterampilan guru diharapkan dapat merangsang peserta didik dalam meningkatkan aktivitas dan kreativitasnya untuk mencapai hasil belajar. Berdasarkan fenomena di lapangan yang dilakukan oleh Anggraeni (2011) dengan menggunakan model pembelajaran kooperatif tipe Course Review Horay pada Siswa kelas IV SD Negeri Sekaran 01 Semarang. Model pembelajaran kooperatif tipe Course Review Horay ini termasuk model pembelajaran inovatif (Uno dan Mohamad, 2015:126) yang dapat meningkatkan aktivitas peserta didik dan menciptakan suasana belajar yang menyenangkan.

Dalam hasil penelitian Anggraeni (2011) terdapat peningkatan kualitas pembelajaran IPS. Keterampilan guru mengalami peningkatan pada setiap siklusnya, pada siklus I memperoleh skor rata-rata 2,6, pada siklus II meningkat menjadi 3,2 dan pada siklus III meningkat hingga 3,8. Selain itu, aktivitas siswa juga menunjukkan peningkatan. Pada siklus I memperoleh skor rata-rata 2,3, pada siklus II memperoleh skor rata-rata 2,6, dan pada siklus III memperoleh skor rata-rata mencapai 3,5. Selanjutnya, persentase ketuntasan belajar siswa juga mengalami peningkatan yaitu pada siklus I persentase ketuntasan belajar baru mencapai $44 \%$, pada siklus II mengalami peningkatan yaitu 67\%, dan pada siklus III mengalami peningkatan yang signifikan yaitu persentase ketuntasan belajar mencapai $93 \%$. Dengan demikian dapat disimpulkan melalui model pembelajaran kooperatif tipe Course Review Horay dapat meningkatkan kualitas pembelajaran yang meliputi keterampilan guru, aktivitas siswa, dan hasil belajar siswa.

Pembelajaran inovatif menekankan pembelajaran yang berpusat pada peserta didik untuk mengkonstruksikan pengetahuannya secara mandiri. Menurut Rogers prinsip belajar dalam teori belajar humanisitik untuk menumbuhkan hasrat peserta didik dalam belajar, belajar yang berarti, belajar tanpa ancaman, belajar atas inisiatif sendiri, dan belajar untuk perubahan (Anam, 2014). Maksudnya peserta didik diarahkan mampu memahami potensi-potensi yang tersimpan pada dirinya. Hal tersebut terlihat dari penelitian Lesilolo (2017) pada sekolah SD Negeri 71 Ambon. Penelitian yang dilakukannya diperoleh informasi tentang realita proses belajar mengajar pendidikan agama kristen dan budi pekerti dengan pendekatan belajar yang mengaktualisasikan diri siswa serta implikasinya yang terdapat SD Negeri 71 Ambon. Instrumen yang digunakan bertujuan untuk mendapatkan dan mengolah data primer maupun sekunder dari hasil wawancara dengan pihak terkait, baik dari kepala sekolah, guru, dan siswa. 
Dari hasil penelitian Lesilolo (2017) penerapan aktualisasi diri siswa menurut Carl, R. Rogers dalam proses belajar mengajar pendidikan agama kristen dan budi pekerti berbasis kurikulum 2013 di kelas IV Sekolah Dasar, sebagai berikut: (1) peserta didik menjadi pembelajar yang aktif dalam berkomunikasi, bertindak, berbudi, dan mencari jawaban dengan usahanya sendiri berdasarkan fakta yang benar, (2) guru tidak menggurui, tetapi guru membangun kepercayaan peserta didik dalam menuangkan ide dalam proses belajar, dan (3) proses belajar mengajar dimulai dari pengalaman peserta didik, baik dari segi kognitif, afektif, dan psikomtor. Oleh sebab itu tujuan pembelajaran inovatif menekankan pada proses keaktifan belajar peserta didik, yang difokuskan pada penerapan pengetahuan dalam kehidupan peserta didik, sehingga pembelajaran terasa lebih bermakna bagi peserta didik itu sendiri.

Pembelajaran inovatif lebih mengarah pada pembelajaran yang berpusat pada peserta didik, pembelajaran tersebut dirancang, disusun, dan dikondisikan untuk menumbuhkan motivasi peserta didik dalam belajar. Hal tersebut terlihat pada penelitian Fitrianingrum (2014) yang membahas tentang peningkatan motivasi belajar IPS melalui metode talking stick. Metode talking stick merupakan salah satu metode pembelajaran inovatif (Susrawan, 2015). Berdasarkan hasil penelitian Fitrianingrum (2014) terdapat peningkatan motivasi belajar IPS kelas IV SD Negeri 3 Jatipohon. Motivasi belajar siswa mengalami peningkatan pada setiap siklusnya. Pada siklus I, dari 31 siswa yang memiliki motivasi rendah sebanyak 8 orang $(25,81 \%)$, yang memiliki motivasi sedang sebanyak 11 orang $(35,48 \%)$, yang memiliki motivasi tinggi sebanyak 10 orang $(32,26 \%)$, dan yang memiliki motivasi sangat tinggi sebanyak 2 orang (6,45\%). Sebaliknya pada tahap siklus 2 mengalami peningkatan lebih baik. Dari 31 siswa yang memiliki motivasi rendah sebanyak 3 orang $(9,68 \%)$, yang memiliki motivasi sedang sebanyak 5 orang $(16,13 \%)$, yang memiliki motivasi tinggi sebanyak 17 orang $(54,84 \%)$, dan yang memiliki motivasi sangat tinggi sebanyak 6 orang. $(19,35 \%)$.

Berdasarkan data tersebut motivasi belajar IPS siswa pada siklus I dan siklus II dengan menggunakan metode talking stick mengalami peningkatan. Keberhasilan pembelajaran ditentukan oleh banyak faktor, baik berasal dari siswa maupun dari guru. Hal itu karena guru mempunyai peranan penting dalam mencapai keberhasilan pada suatu pembelajaran. Guru harus mampu merangsang dan membangkitkan motivasi siswa dalam belajar (Fitrianingrum, 2014). Menurut Maslow terdapat dua macam kebutuhan dalam diri seseorang, yaitu kebutuhan dasar dan kebutuhan untuk bertumbuh (berkembang) (Choirudin, 2013). Kedua kebutuhan tersebut mempengaruhi motivasi siswa dalam belajar. Oleh sebab itu guru diharapkan mempunyai insting yang kuat dalam membaca situasi dan kondisi siswa dalam proses pembelajaran.

Strategi pembelajaran memfokuskan pada kegiatan pembelajaran yang dilakukan guru dan peserta didik untuk menciptakan pembelajaran yang efektif dan efisien. Penerapan teori belajar humanistik dalam mengimplementasikan pembelajaran inovatif akan membantu guru dalam menciptakan pembelajaran yang efektif sehingga upaya pembelajaran akan selalu diarahkan dan dilakukan untuk mencapai tujuan pembelajaran. Hal tersebut terlihat dari penelitian Ronawati (2016) 
yang menerapkan model pembelajaran kooperatif tipe STAD untuk meningkatkan hasil belajar siswa pada mata pelajaran IPA di kelas IV SDN 3 Tambun Tolitoli. Menurut Uno dan Mohamad (2015:107) model pembelajaran kooperatif tipe STAD termasuk salah satu model pembelajaran inovatif. Model ini dapat digunakan untuk mengerjakan materi yang kompleks dan dapat membantu guru dalam mencapai tujuan pembelajaran.

Penelitian yang dilakukan Ronawati (2016) dilaksanakan dalam 2 siklus yang terdiri dari 4 tahapan, yaitu, perencanaan, pelaksanaan, observasi, dan refleksi dengan jumlah siswa 16 orang. Dari hasil tindakan siklus I di peroleh ketuntasan belajar klasikal 25\% dengan nilai rata-rata 60.62. Dari hasil tindakan siklus II diperoleh ketuntasan belajar klasikal 100\% dengan nilai rata-rata 90.31. Berdasarkan hasil penelitian Ronawati (2016) dapat dikemukakan bahwa dengan menerapkan model kooperatif tipe STAD membuat siswa lebih aktif dalam kegiatan pembelajaran. Siswa lebih berani berbicara, mengajukan, dan menjawab pertanyaan. Oleh karena itu penerapan kooperatif tipe STAD memungkinkan untuk di jadikan sebagai salah satu model pembelajaran dalam meningkatkan hasil belajar siswa dalam belajar IPA di SDN 3 Tambun Kecamatan Baolan Kabupaten Tolitoli.

Model pembelajaran kooperatif tipe STAD memberikan seluruh siswa peluang untuk berdiskusi dengan anggota kelompok di dalam kelas. Model ini dapat melatih siswa berperan aktif dalam proses pembelajaran (Yudiasa, Dibia, dan Made, 2016). Model pembelajaran kooperatif tipe STAD sangat sederhana sehingga siswa akan termotivasi dalam bekerjasama dan menjawab pertanyaan yang diberikan oleh temannya. Apabila motivasi belajar telah terbentuk maka siswa akan tekun dalam belajar. Hal ini berpengaruh positif terhadap peningkatan hasil belajar siswa, sehingga ada hubungan timbal balik antara motivasi belajar dengan hasil belajar. Menurut Uno seseorang yang merasa senang terhadap sesuatu ditunjukkan melalui tingkah laku yang dapat meningkatkan motivasinya dalam melakukan kegiatan (Yudiasa, Dibia, dan Made, 2016). Hal ini senada dengan pendapat Combs tentang konsep meaning (makna atau arti) dalam proses belajar. Menurut konsep meaning (makna atau arti) belajar terjadi apabila mempunyai arti bagi individu tersebut (Wigati dan Muhtarom, 2017). Maksudnya siswa akan senang belajar apabila pelajaran tersebut memiliki makna dan arti bagi peserta didik itu sendiri.

\section{SIMPULAN}

Teori belajar humanistik merupakan sebuah teori yang masuk ke dalam ruang lingkup pendidikan yang dijadikan sebagai materi untuk mengembangkan potensi yang ada peserta didik. Tujuan belajar menurut aliran humanistik untuk memanusiakan manusia. Proses belajar dianggap berhasil jika peserta didik memahami lingkungan dan dirinya sendiri. Di dalam teori belajar humanistik guru berperan sebagai fasilitator bagi peserta didik, guru memberikan motivasi dan kesadaran mengenai makna belajar dalam kehidupan peserta didik. Oleh sebab itu dibutuhkan teori belajar humanistik dalam pembelajaran inovatif untuk merubah perilaku peserta didik ke arah yang lebih baik. Pembelajaran inovatif dilahirkan dengan mempetimbangkan karakteristik peserta didik, kondisi lingkungan peserta didik, dan sarana-prasarana yang tersedia bagi peserta didik itu sendiri, sehingga 
lebih menantang dan menumbuhkembangkan semangat peserta didik untuk belajar secara mandiri yang mempermudah pencapaian tujuan belajar.

Pembelajaran inovatif lebih mengarah pada pembelajaran yang berpusat pada peserta didik, pembelajaran tersebut dirancang, disusun, dan dikondisikan untuk menumbuhkan motivasi peserta didik dalam belajar. Menurut Rogers prinsipprinsip belajar secara humanistik pada dasarnya bertumpu pada faktor kebebasan dan perbedaan individu (peserta didik) dalam pendidikan. Oleh sebab itu peserta didik akan lebih mengenal dirinya, menerima dirinya, dan merasa bebas dalam memilih dan berbuat menurut individualitas dengan penuh tanggung jawab. Selain itu menurut Combs dalam kegiatan belajar guru sebagai tenaga pendidik tidak boleh memaksakan materi yang tidak disukai oleh peserta didik. Hal itu karena peserta didik belajar sesuai dengan apa yang diinginkannya. Dengan demikian pembelajaran inovatif bertujuan untuk merangsang keaktifan belajar peserta didik, yang difokuskan pada penerapan pengetahuan dalam kehidupan peserta didik, sehingga pembelajaran terasa lebih bermakna dan peserta didik belajar atas kemauannya sendiri

Kreativitas dan keterampilan guru dalam memilih strategi pembelajaran inovatif disusun berdasarkan berbagai pertimbangan sesuai dengan situasi, kondisi, dan lingkungan yang akan dihadapi. Hal itu karena pemilihan strategi pembelajaran dapat memberikan kontribusi kepada peserta didik dalam pensharingan ilmu pengetahuan. Menurut Maslow peserta didik tidak akan mampu belajar apabila kebutuhan dasarnya belum terpenuhi yang dapat mempengaruhi motivasinya dalam belajar. Oleh sebab itu guru sebagai tenaga pendidik diharapkan mempunyai insting yang kuat dalam membaca situasi dan kondisi peserta didik dalam proses pembelajaran. Pemilihan strategi pembelajaran bertujuan untuk mengembangkan potensi-potensi yang ada pada peserta didik baik dari segi kognitif, afektif, dan psikomotor.

\section{REFERENSI}

Abidin, Z. (2002). Filsafat Manusia: Memahami Manusia Melalui Filsafat. Bandung: PT. Remaja Rosdakarya.

Aini, S. N., \& Sudira, P. (2015). Pengaruh Strategi Pembelajaran, Gaya Belajar, Sarana Praktik, dan Media Terhadap Hasil Belajar Patiseri SMK SeGerbangkertasusila. Jurnal Pendidikan Vokasi, 5(1), 88-102.

Alauddin. (2015). Prinsip dan Implikasi Teori Belajar Humanistik dalam Pembelajaran. Jurnal Pendidikan IQRA, 3(1).

Anam, N. (2014). Konsep Belajar dan Pembelajaran Humanistik Perspektif Paolo Freire dan Kh. Abdul Wahid Hasyim. Jurnal Al-Fitrah, 9(1).

Anggraeni, D. (2011). Peningkatan Kualitas Pembelajaran IPS melalui Model Pembelajaran Kooperatif Tipe Course Review Horay pada Siswa Kelas IV SD Negeri Sekaran 01 Semarang (Inproving Social Instructional Quality by Cooperative Model, Course Review Horay Type At Fourth SDN). Jurnal Kreatif: Jurnal Kependidikan Dasar, 1(2).

Ansyar, M. (2015). Kurikulum: Hakikat, Fondasi, Desain, dan Pengembangan. Jakarta:

Kencana Prenadamedia Group. 
Arbayah, A. (2013). Model Pembelajaran Humanistik. Dinamika Ilmu: Jurnal Pendidikan, 13(2).

Armiati. (2016). Pembelajaran yang Menyenangkan dalam Perspektif Teori Humanistik melalui Implementasi Video Pembelajaran Cooperative Learning. Jurnal Pengetahuan, Sosial, dan Budaya, 1(1).

Aswita, D. (2015). Identifikasi Masalah yang Dihadapi Guru Biologi dalam Pelaksanaan Pembelajaran pada Materi Ekosistem. Biotik: Jurnal Ilmiah Biologi Teknologi dan Kependidikan, 3(1), 63-68.

Atamimi, N. (2015). Keterampilan Psikologis Model Bimbingan Konseling Proaktif untuk Guru Sekolah Dasar. Jurnal Cakrawala Pendidikan, 3(3).

Choirudin, F. (2013). Motivasi Mahasiswa Fakultas Pendidikan Psikologi Yang Mengikuti Ormawa Ditinjau Dari Memiliki Pengalaman Menjadi Pengurus Dan Tidak Memiliki Pengalaman Menjadi Pengurus OSIS di SMA. Skripsi Jurusan Psikologi-Fakultas Pendidikan Psikologi UM.

Fitrianingrum, R. (2014). Peningkatan Motivasi Belajar IPS melalui Metode Talking Stick Pada Siswa Kelas 4 SD Negeri 3 Jatipohon Grobogan Tahun Pelajaran 2013/2014 (Doctoral dissertation, Universitas Muhammadiyah Surakarta).

Haris, M. (2016). Teori Kognitif dan Humanistik sebagai Teori untuk Mempermudah Proses Belajar bagi Siswa. Prosiding Seminar Nasional: Orientasi Pembelajaran Bahasa dan Sastra Indonesia dalam Kurikulum 2013. Yogyakarta: Fakultas Keguruan dan Ilmu Pendidikan Universitas Ahmad Dahlan.

Harahap, N. (2014). Penelitian Kepustakaan. Jurnal Iqra', 8(1).

Hanafy, M. S. (2014). Konsep Belajar dan Pembelajaran. Lentera Pendidikan, 17(1), 6679.

Hidayat, H. S. (2008). Efektivitas Strategi Pembelajaran dan Motivasi Belajar terhadap Hasil Belajar IPA. Sosiohumaniora, 10(1), 82.

Hera, R. (2017). Studi Kasus Permasalahan dalam Proses Pembelajaran Konsep Genetika di SMA Negeri 2 Seulimum Kabupaten Aceh Besar. Genta Mulia: Jurnal Ilmiah Pendidikan, 8(1).

Hia, Y. D., Sumarni, dan Armiati. (2016). Pelatihan Metode Pembelajaran Inovatif untuk Meningkatkan Profesionalisme Guru SMA. Jurnal Pelangi. 8(2).

Hilmi. (2012). Pendekatan Humanistik dalam Belajar. Jurnal Pendidikan dan Pembelajaran, 6(2).

Lesilolo, H. J. (2017). Aktualisasi Diri Siswa dalam Proses Pembelajaran Pendidikan Agama Kristen dan Budi Pekerti Berdasarkan Perspektif Carl R. Rogers. Jurnal Bimbingan dan Konseling Terapan, 1(1).

Marzuki, A. (2017). Model-model Pembelajaran PAI Inovatif dan Kontekstual. Jurnal Al-Ghazwah, 1(1).

Mayasari, S. (2017). Filsafat Pendidikan Humanisme dalam Perspektif Pembelajaran Bahasa Inggris bagi Peserta Didik di Tingkat Sekolah Menengah Atas: Sebuah Kajian Teori. Jurnal Dosen Universitas PGRI Palembang.

Manurung, R. T. (2012). Pendidikan Antikorupsi Sebagai Satuan Pembelajaran Berkarakter dan Humanistik. Jurnal Sosioteknologi, 11(27), 227-239. 
Mendari, A. S. (2010). Aplikasi Teori Hierarki Kebutuhan Maslow dalam Meningkatkan Motivasi Belajar Mahasiswa. Jurnal Ilmiah Universitas Katolik Widya Mandala Madium, 34(1).

Moeheriono. (2006). Pengaruh Motivasi Kerja terhadap Prestasi Kerja (Studi Kasus pada Tiga Perusahaan Makanan dan Minuman Terbuka/Tbk) di Jawa Timur. Jurnal Ekonomi dan Keuangan, 11(2).

Mulkhan, A. M. (2002). Nalar Spiritual Pendidikan: Solusi Problem Filosofis Pendidikan Islam. Yogyakarta: Tiara Wacana.

Munawar, M., Prasetyo, A., dan Pusari, R. W. (2013). Pengembangan Model Pembelajaran Inovatif melalui Pendekatan in House Training Berbasis Kearifan Budaya Lokal. PAUDIA, 2(1).

Muniroh, S. M. (2011). Penerapan Aliran Psikologi Humanistik Dalam Proses Pembelajaran. Edukasia Islamika, 9(1).

Mustami, M. K. (2015). Model SM2CL untuk Pembelajaran Biologi yang Inovatif. Jurnal Biotek, 3(1).

Purwoko, B. (2017). Studi Kepustakaan Mengenai Landasan Teori dan Praktik Konseling Expressive Writing. Jurnal BK UNESA, 8(1).

Rachmahana, R. S. (2008). Psikologi Humanistik dan Aplikasinya dalam Pendidikan. Jurnal Pendidikan Islam, 1(1).

Rahmawati, N. D. (2016). Model Pembelajaran Inovatif Matematika pada Mahasiswa. Jurnal e-DuMath, 2(2).

Rahmi. (2013). Menciptakan Pembelajaran Matematika yang Kreatif dan Menyenangkan. Jurnal Pelangi, 6(1).

Ratu, B. (2014). Psikologi Humanistik (Carl Rogers) dalam Bimbingan dan Konseling. Jurnal Kreatif, 17(3).

Riyanton, M. (2015). Pendidikan Humanisme dan Implementasinya dalam Pembelajaran Bahasa Indonesia. Jurnal Lingua Idea, 6(1).

Rofikoh, E. (2014). Pengaruh Pembelajaran Humanistik Terhadap Keaktifan Belajar dan Hasil Belajar Matematika Siswa Kelas IX SMP Negeri 1 Bringin Kabupaten Semarang Semester I Tahun Ajaran 2014/2015 (Doctoral dissertation, Program Studi Pendidikan Matematika FKIP-UKSW).

Ronawati, R. (2016). Penerapan Model Pembelajaran Kooperatif Tipe STAD Untuk Meningkatkan Hasil Belajar Siswa Pada Mata Pelajaran IPA Di Kelas IV SDN 3 Tambun Tolitoli. Jurnal Kreatif Tadulako Online, 4(1).

Siregar, R., \& Situmorang, J. (2014). Pengaruh Strategi Pembelajaran dan Tipe Kepribadian Terhadap Hasil Belajar Strategi Belajar Mengajar. Jurnal Teknologi Pendidikan (JTP), 7(2).

Sudiarta, I. N., Sukadi, M. P., \& Tegeh, I. M. (2014). Penerapan Model Pembelajaran Kooperatif Bernuansa Kearifan Lokal Menggunakan Pendekatan Humanis untuk Meningkatkan Hasil Belajar Pkn pada Siswa Kelas VIII A SMP Negeri 3 Manggis Semester 2 Tahun Pelajaran 2012/2013. Jurnal Teknologi Pembelajaran, 4(1).

Sanusi, U. (2013). Pembelajaran dengan Pendekatan Humanistik: Penelitian pada MTs Negeri Model Cigugur Kuningan. Jurnal Pendidikan Agama Islam, 11(2). 
Sarwi, S., Supriyadi, S., dan Sudarmin, S. (2013). Implementasi Model Pembelajaran Inovatif untuk Mengembangkan Nilai Karakter Siswa SMP. Jurnal Penelitian Pendidikan, 30(2).

Suharmanto, A. (2008). Perencanaan dan Pembelajaran Inovatif. (Buku Ajar). Semarang: Fakultas Teknik Universitas Negeri Semarang.

Sunardi. (2015). Pembelajaran Inovatif pada Mata Pelajaran IPS dan Sejarah di Sekolah (Pembelajaran yang Penuh Makna untuk Memaksimalkan Kreatifitas Peserta didik). Jurnal Widya Sari, 17(2).

Sunhaji. (2008). Strategi Pembelajaran: Strategi Pembelajaran: Konsep dan Aplikasinya. Jurnal Pemikiran Alternatif Pendidikan, 13(3).

Susrawan, I. N. A. (2015). Penerapan Metode Pembelajaran Inovatif (Talking Stick dan EKSTRIM) untuk Meningkatkan Aktivitas dan Hasil Belajar Keterampilan Berbicara Siswa Kelas $X$ SMA N 1 Kubu Karangasem. Jurnal Bakti Saraswati (JBS), 4(01).

Susanti, Y., Wahjoedi, dan Utaya, S. (2016). Aktivitas Belajar Tematik Siswa Kelas V SD Melalui Model Pembelajaran Kooperatif Tipe STAD. Prosiding Seminar Nasional. Malang: Pascasarjana Universitas Negeri Malang.

Uno, H. B., dan Mohamad, N. (2015). Belajar dengan Pendekatan PAIKEM. Jakarta. PT. Bumi Aksara.

Widyaningrum, H. K., dan Rahmanumeta, F. M. R. (2016). Pentingnya Strategi Pembelajaran Inovatif Dalam Menghadapi Kreativitas Siswa Di Masa Depan. In Proceedings International Seminar FoE (Faculty of Education) (pp. 268-277).

Wahyudin, Y. (2009). Teori Belajar Humanistik Carl Ransom Rogers dan Implikasinya terhadap Metode Pembelajaran Pendidikan Agama Islam.

Wigati, I., dan Muhtarom, M. (2017). Paradigma Humanisme Pendidikan Islam pada Anak Usia Dini. Raudhatul Athfal: Jurnal Pendidikan Islam Anak Usia Dini, 1(1), 44-60.

Yasin, M. (2017). Teori Humanistik dalam Pembelajaran. Jurnal An-Nur, 1(01), 46-57.

Yanasari, P. (2016). The Humanistic Aprroach to Change and the Development of Behavior in the Realm Of Education. Nuansa, 9(2).

Yudiasa, I. K., Dibia, I. K., \& Made Sumantri, M. P. (2016). Penerapan Model Pembelajaran STAD untuk Meningkatkan Motivasi dan Hasil Belajar IPA Kelas V. MIMBAR PGSD Undiksha, 4(3). 